\section{The relationship between dental anxiety and dental pain in children aged 18 to 59 months: a study in Recife, Pernambuco State, Brazil}

\author{
A relação entre ansiedade odontológica e a dor de \\ dente em crianças com idade entre 18 e 59 meses: \\ estudo em Recife, Pernambuco, Brasil
}

\author{
${ }^{1}$ Faculdade de Odontologia \\ de Pernambuco, Universidade \\ de Pernambuco, Recife, \\ Brasil. \\ Correspondence \\ M. M. T. Oliveira \\ Faculdade de Odontologia de \\ Pernambuco, Universidade \\ de Pernambuco. \\ Rua Dona Julieta 90, apto. 303 \\ Recife, $P E$ \\ 52041-550, Brasil. \\ mariemichelle@oi.com.br \\ marieborba@yahoo.com.br
}

\section{Abstract}

The aim of this study was to evaluate anxiety and pain related to dental treatment in children under the age of five years. This cross sectional study was carried out with 2,735 children of both sexes. Socioeconomic data, dental anxiety and dental pain experience, as well as the assessment of the child's oral health status, were obtained through a questionnaire answered by the child's parent or guardian. Dental anxiety was measured using the Dental Anxiety Question (DAQ). The prevalence of dental anxiety was $34.7 \%$ and that of dental pain was $9.1 \%$. There was an association between these two variables $(p<0.0001)$. There was also an association between dental pain, age, family income and assessment of oral health status. The poorest rating of the child's oral health and the lowest family income were correlated with the highest percentages of a history of dental pain. Dental anxiety was related to a history of dental pain in children under the age of five years.

Dental Anxiety; Preschool Child; Toothache; Oral Health
Michelle Marie T. Oliveira ${ }^{1}$

Viviane Colares 1

\section{Introduction}

The experience of pain, normally conceived as a consequence of disorders of the human body organs or systems, is considered a major public health problem. From an oral health perspective, untreated dental caries usually leads to a specific kind of pain, dental pain ${ }^{1}$.

Dental anxiety and associated fear-related behaviors are some of the most difficult aspects of child patient management. The most common sources of directly anticipated fear are invasive medical or dental experiences because of their pain-related etiology 2

The etiology of dental fear in children is multifactorial. Increased dental fear has been related to previous painful dental experiences, increased general fears and the negative influence of the mother's dental fear 3 .

Klingberg et al. 4 also found that child dental fear was related to general fears, mother's dental fear and child's age. They reported that clinical behavior management problems in Swedish children were related to age, previous negative experiences of dental treatments, anxiety when meeting strangers, and dental fear in the family.

Caraciolo \& Colares 5 set out to determine the prevalence of related fear and/or anxiety to the dental visit in preschoolers. 358 five-year-old children of both sexes registered at public or private schools in the city of Recife, Pernambuco State, Brazil, participated in the study. The data, col- 
lected through the application of a questionnaire in the form of an interview with the children's parents or guardians, was submitted to statistical analysis. Most of the parents or guardians reported that their child presented fear and/or anxiety related to the dental visit (41.1\%), the prevalence being higher among preschoolers of low income families attending a public school (55.3\%). In relation to gender, no significant associations ( $p>0.005$ ) with dental fear and/or dental anxiety were evidenced.

Painful sensations are feared by people of all ages, particularly by children. There are various reasons which explain why pain in children does not receive the same attention as pain in adults. One of them is health professionals' difficulty to measure pain in infants ${ }^{6}$.

Anxious people tend to overestimate the intensity of aversive events such as fear and pain. When an aversive event has been experienced personally, prediction is based on experience and is possibly less subject to bias due to anxiety. Therefore, people predisposed to respond fearfully to pain are at an increased risk of ending up in a vicious circle of anxiety: fear of pain, avoidance of dental treatment, more pain 7 .

The aim of the present investigation was to study the relationship between dental anxiety and dental pain in children under the age of five in Recife.

\section{Methods}

This study was carried out in Recife, the capital of Pernambuco state in the northeast of Brazil, which in 2005 had a population of 1,501,008 inhabitants.

In Brazil, a national polio immunization campaign is held for one or two days, twice a year to vaccinate all children under the age of five against polio. On this occasion parents take their children to the nearest health center. According to the Ministry of Health, Pernambuco was the only Brazilian state that managed to vaccinate $100 \%$ of its children in 2005. The data for this study was collected during the immunization campaign that took place in Recife in 2006.

A sample of 1,460 children was calculated considering a total of 133,797 children aged under five who were vaccinated in 2005. For the calculation of the sample the Epi Info version 6.0 (Centers for Disease Control and Prevention, Atlanta, USA) statistical program for microcomputers was used with a $95 \%$ confidence interval and error no greater than $2.5 \%$ with a 0.5 level of statistical significance. The prevalence of dental anxiety in 5-year-old children was set at $40 \% 5$.
However, the total number of children in the study $(2,735)$ almost doubled that of the sample initially calculated. The sample was collected in 21 randomly selected health centers.

Socioeconomic data was obtained through an interview with each child's parent or guardian. In order to identify social status, the family income was considered, given as a multiple of the Brazilian minimum wage. Data on dental anxiety was measured using the Dental Anxiety Question (DAQ) ${ }^{8}$ which contains this single-item measure of dental anxiety "Are you a fraid of going to the dentist?", with four possible answers: "no"; "a little"; "yes, quite"; "yes, very", corresponding respectively to the scores 1-4. In this study, the question used was: "Do you think that your child is afraid of going to the dentist?" because the parent or guardian was to evaluate the child's fear. The child's parent or guardian was asked about the child's oral health status, whether there was any history of dental pain since the child's birth and whether the child had ever seen a dentist.

On vaccination days, the interviewer invited the parent or guardian to participate. The parents or guardians were informed of the purpose and method of this study and their informed consent was obtained.

The pilot study, conducted with 83 children, set out to perform the validation of the instruments (DAQ) and calibration of the researcher, in addition to any adjustments required. The questionnaires were submitted to face validity and test-retest. The intra-examiner agreement was substantial (kappa $=0.80$ ) and the inter-examiner value was kappa $=0.79$

Descriptive statistical techniques and the chisquare test were used to analyze data. According to the independent variables selected in the bivariate study, a logistic regression model was adjusted to each dependent variable to explain the influence of the presence of dental pain and anxiety on dental treatment.

The study design was approved by the Ethics Committee of the University of Pernambuco (protocol $\left.n^{\circ} .044 / 06\right)$, according to the Helsinki declaration (1964, revised in 1975, 1983, 1989, 1996 and 2000).

\section{Results}

Of all the children studied, $29.1 \%$ were aged 36 47 months; $52.6 \%$ were boys and almost half of these children were from low-income families. In most cases, childcare was performed by the mother (Table 1).

The information on gender was not available for 880 children because this data were not col- 
Distribution of children according to age, gender, family income and children's parent/guardian.

\begin{tabular}{|c|c|c|}
\hline Variable & $\mathrm{n}$ & $\%$ \\
\hline \multicolumn{3}{|l|}{ Age (months) } \\
\hline $18-23$ & 394 & 14.4 \\
\hline $24-35$ & 753 & 27.5 \\
\hline $36-47$ & 797 & 29.1 \\
\hline $48-59$ & 791 & 28.9 \\
\hline Total & 2,735 & 100.0 \\
\hline \multicolumn{3}{|l|}{ Gender * } \\
\hline Female & 880 & 47.4 \\
\hline Male & 975 & 52.6 \\
\hline Total & 1,855 * & 100.0 \\
\hline \multicolumn{3}{|c|}{ Family income (multiple of Brazilian minimum wage) ** } \\
\hline 1 & 1,214 & 47.5 \\
\hline 2 & 424 & 16.6 \\
\hline 3 & 231 & 9.0 \\
\hline 4 & 175 & 6.9 \\
\hline 5 & 132 & 5.2 \\
\hline 6 & 77 & 3.0 \\
\hline 7 or more & 303 & 11.9 \\
\hline Total & 2,556 ** & 100.0 \\
\hline \multicolumn{3}{|l|}{ 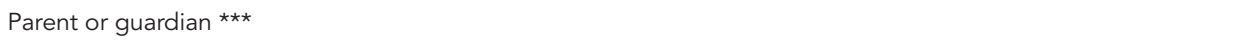 } \\
\hline Mother & 1,788 & 65.5 \\
\hline Father & 397 & 14.5 \\
\hline Grandfather/Grandmother & 194 & 7.1 \\
\hline Uncle/Aunt & 227 & 8.3 \\
\hline Other & 124 & 4.5 \\
\hline Total & $2,730 * \star \star$ & 100.0 \\
\hline
\end{tabular}

* This information was not available for 880 children;

** This information was not available for 179 children;

*** This information was not available for 5 children.

lected in the first day of vaccination in account of a failure in the questionnaire. However, gender information collected in the second day of vaccination amounted to 1,855 children, which surpassed the calculation of the initial sample $(1,460)$.

The prevalence of dental anxiety was $34.7 \%$ and children aged 24-35 months and children from low-income families presented the highest percentage (Table 2).

OR values showed that the probability of a child in the sample experienced dental anxiety increases if he or she is in the 24-36-month age group, has never seen a dentist, but had some history of dental pain (Table 3).

Of all the children, $9.1 \%$ had a history of dental pain. There was a strong association between dental pain, age, family income and assessment of oral health status by the parent or guardian
(Table 4). The poorest rating of the child's oral health status by the parent or guardian, as well as the lowest family income, corresponded to the highest percentages of a history of dental pain. The older the child, the greater the dental pain experience.

OR values showed that the probability that a child in the sample experienced dental pain increases if he or she is in the 48-59-month age group; if the child is from a low income family; if the child has already seen a dentist and if the child's oral health was reported as bad (Table 5).

There was a strong association between dental anxiety and dental pain experience (Table 6). 
Table 2

Distribution of children according to dental anxiety, age, gender and family income.

\begin{tabular}{|c|c|c|c|c|c|c|c|c|c|c|c|}
\hline \multirow[t]{3}{*}{ Variable } & \multicolumn{6}{|c|}{ Dental anxiety } & & & \multicolumn{2}{|c|}{ Total } & \multirow[t]{3}{*}{ p-value } \\
\hline & \multicolumn{2}{|c|}{ No } & \multicolumn{2}{|c|}{ A little } & \multicolumn{2}{|c|}{ Yes, quite } & \multicolumn{2}{|c|}{ Yes, very } & \multirow[b]{2}{*}{$\mathbf{n}$} & \multirow[b]{2}{*}{$\%$} & \\
\hline & $\mathrm{n}$ & $\%$ & $\mathrm{n}$ & $\%$ & $\mathbf{n}$ & $\%$ & $\mathbf{n}$ & $\%$ & & & \\
\hline \multicolumn{12}{|l|}{ Gender } \\
\hline Male & 578 & 66.1 & 115 & 13.1 & 99 & 11.3 & 83 & 9.5 & 875 & 100.0 & 0.4766 \\
\hline Female & 500 & 65.0 & 104 & 13.5 & 103 & 13.4 & 62 & 8.1 & 769 & 100.0 & \\
\hline Total & 1,078 & 65.6 & 219 & 13.3 & 202 & 12.3 & 145 & 8.8 & $1,644 * \star$ & 100.0 & \\
\hline \multicolumn{12}{|c|}{ Age (months) } \\
\hline $18-23$ & 216 & 61.5 & 60 & 17.1 & 37 & 10.5 & 38 & 10.8 & 351 & 100.0 & $<0.0001$ * \\
\hline $24-35$ & 405 & 59.7 & 104 & 15.4 & 99 & 14.6 & 70 & 10.3 & 678 & 100.0 & \\
\hline $36-47$ & 491 & 66.4 & 77 & 10.4 & 108 & 14.6 & 64 & 8.7 & 740 & 100.0 & \\
\hline $48-59$ & 525 & 71.1 & 73 & 9.9 & 72 & 9.8 & 68 & 9.2 & 738 & 100.0 & \\
\hline Total & 1,637 & 65.3 & 314 & 12.5 & 316 & 12.6 & 240 & 9.6 & $2507 * \star \star$ & 100.0 & \\
\hline \multicolumn{12}{|c|}{ Family income } \\
\hline \multicolumn{12}{|c|}{ (Brazilian minimum wage) } \\
\hline 1 & 663 & 62.1 & 145 & 13.6 & 140 & 13.1 & 120 & 11.2 & 1,068 & 100.0 & 0.0092 * \\
\hline 2 & 254 & 65.0 & 51 & 13.0 & 48 & 12.3 & 38 & 9.7 & 391 & 100.0 & \\
\hline 3 & 144 & 64.4 & 31 & 14.1 & 24 & 10.9 & 21 & 9.6 & 220 & 100.0 & \\
\hline$\geq 4$ & 470 & 70.7 & 63 & 9.5 & 89 & 13.4 & 43 & 6.5 & 665 & 100.0 & \\
\hline Total & 1,531 & 65.3 & 290 & 12.4 & 301 & 12.8 & 222 & 9.5 & 2,344 \# & 100.0 & \\
\hline
\end{tabular}

* Pearson chi-square test;

** This information was not available for 1,091 children;

*** This information was not available for 228 children;

\# This information was not available for 391 children.

Table 3

Logistic regression analysis for the dental anxiety variable.

\begin{tabular}{|c|c|c|c|}
\hline \multirow[t]{2}{*}{ Variable } & \multicolumn{2}{|c|}{ OR $(95 \% \mathrm{Cl})$} & \multirow[t]{2}{*}{$p$-value } \\
\hline & $\begin{array}{c}\text { Observed in } \\
\text { bivariable analysis }\end{array}$ & $\begin{array}{l}\text { Adjusted to } \\
\text { the model }\end{array}$ & \\
\hline Constant & & & $<0.001$ * \\
\hline Age (months) & & & $<0.001$ * \\
\hline $18-23$ & $1.54(1,18-2.01)$ & $1.74(1.30-2.32)$ & $<0.001$ * \\
\hline $24-35$ & $1.66(1.33-2.07)$ & $1.86(1.46-2.36)$ & $<0.001$ * \\
\hline $36-47$ & $1.25(1.00-1.56)$ & $1.34(1.06-1.69)$ & 0.016 * \\
\hline $48-59$ & 1.00 & 1.00 & $<0.001$ * \\
\hline \multicolumn{4}{|c|}{ Visits to the dentist } \\
\hline Yes & 1.00 & 1.00 & $0.001 *$ \\
\hline No & $1.42(1.20-1.68)$ & $1.36(1.13-1.63)$ & \\
\hline \multicolumn{4}{|c|}{ History of dental pain } \\
\hline Yes & $1.63(1.24-2.14)$ & $2.24(1.67-3.01)$ & $<0.001$ * \\
\hline No & 1.00 & 1.00 & \\
\hline
\end{tabular}

* Significant at 5.0\%. 
Distribution of children according to dental pain related to age, gender, family income and assessment of oral health status by parent or guardian.

\begin{tabular}{|c|c|c|c|c|c|c|c|}
\hline \multirow[t]{3}{*}{ Variable } & \multicolumn{4}{|c|}{ History of dental pain } & \multicolumn{2}{|c|}{ Total } & \multirow[t]{3}{*}{$\mathrm{p}$-value } \\
\hline & \multicolumn{2}{|c|}{ Yes } & \multicolumn{2}{|c|}{ No } & \multirow[b]{2}{*}{$\mathrm{n}$} & \multirow[b]{2}{*}{$\%$} & \\
\hline & $\mathbf{n}$ & $\%$ & $\mathrm{n}$ & $\%$ & & & \\
\hline \multicolumn{8}{|l|}{ Gender } \\
\hline Male & 90 & 9.2 & 884 & 90.8 & 974 & 100.0 & 0.9299 * \\
\hline Female & 80 & 9.1 & 797 & 90.9 & 877 & 100.0 & \\
\hline Total & 170 & 9.2 & 1,681 & 90.8 & $1,851 \star \star$ & 100.0 & \\
\hline \multicolumn{8}{|c|}{ Age (months) } \\
\hline $18-23$ & 5 & 1.3 & 386 & 98.7 & 391 & 100.0 & $<0.0001$ * \\
\hline $24-35$ & 34 & 4.5 & 718 & 95.5 & 752 & 100.0 & \\
\hline $36-47$ & 66 & 8.3 & 730 & 91.7 & 796 & 100.0 & \\
\hline $48-59$ & 142 & 18.0 & 646 & 82.0 & 788 & 100.0 & \\
\hline Total & 247 & 9.1 & 2,480 & 90.9 & 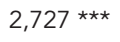 & 100.0 & \\
\hline \multicolumn{8}{|c|}{ Family income (multiple } \\
\hline \multicolumn{8}{|c|}{ of the Brazilian minimum wage) } \\
\hline 1 & 149 & 12.3 & 1,065 & 87.7 & 1,214 & 100.0 & $<0.0001$ * \\
\hline 2 & 35 & 8.3 & 387 & 91.7 & 422 & 100.0 & \\
\hline 3 & 20 & 8.7 & 210 & 91.3 & 230 & 100.0 & \\
\hline$\geq 4$ & 30 & 4.4 & 653 & 95.6 & 683 & 100.0 & \\
\hline Total & 234 & 9.2 & 2,315 & 90.8 & 2,549 \# & 100.0 & \\
\hline \multirow{2}{*}{\multicolumn{8}{|c|}{$\begin{array}{l}\text { Assessment of oral health } \\
\text { status by parent/guardian }\end{array}$}} \\
\hline & & & & & & & \\
\hline Excellent & 17 & 4.2 & 386 & 95.8 & 403 & 100.0 & $<0.0001$ * \\
\hline Good & 91 & 5.8 & 1,469 & 94.2 & 1,560 & 100.0 & \\
\hline Fair & 93 & 14.7 & 541 & 85.3 & 634 & 100.0 & \\
\hline Bad & 33 & 32.7 & 68 & 67.3 & 101 & 100.0 & \\
\hline Terrible & 13 & 48.2 & 14 & 51.8 & 27 & 100.0 & \\
\hline Total & 247 & 9.1 & 2,478 & 90.9 & 2,725 \#\# & 100.0 & \\
\hline
\end{tabular}

* Chi-square test;

** This information was not available for 884 children;

*** This information was not available for 8 children;

\# This information was not available for 186 children;

\#\# This information was not available for 10 children.

\section{Discussion}

In this study, dental anxiety and gender were not associated among children aged under five, which is in agreement with Caraciolo \& Colares 5 . However, age was strongly associated with dental anxiety, in agreement with Klingberg et al. 4 .

Socioeconomic status was shown to be an important factor related to dental anxiety, since the higher thefamilyincome, thelower the dental anxiety rating. This association has been described by other authors such as Majstorovic \& Veerkamp 2 and Caraciolo \& Colares 5 . Armfield et al. 9 found that people from poor socioeconomic backgrounds have a higher prevalence of dental fear.
Although this study investigated very young children (the under-fives), a significant percentage $(9.1 \%)$ had a history of dental pain. Slade et al. ${ }^{10}$ pointed out that $11.8 \%$ of 5 -year-old children reported a history of toothache and that there was a strong association between toothache, age, family income and oral health status. According to them, pain thresholds varied according to socioeconomic status and were also influenced by other social and cultural factors.

Children with severe caries complained of toothache, had difficulty eating certain foods, were absent from school, were ashamed to smile, and stopped playing with other children because of their teeth 11 . 
Table 5

Logistic regression analysis for history of dental pain.

\begin{tabular}{|c|c|c|c|}
\hline \multirow[t]{2}{*}{ Variable } & \multicolumn{2}{|c|}{ OR $(95 \% \mathrm{Cl})$} & \multirow[t]{2}{*}{$\mathrm{p}$-value } \\
\hline & $\begin{array}{c}\text { Observed in } \\
\text { bivariate analysis }\end{array}$ & $\begin{array}{l}\text { Adjusted to } \\
\text { the model }\end{array}$ & \\
\hline Constant & & & $<0.001^{*}$ \\
\hline Age (months) & & & $<0.001^{\star}$ \\
\hline $18-23$ & 1.00 & 1.00 & \\
\hline $24-35$ & $3.65(1.42-9.42)$ & $2.48(0.95-6.48)$ & 0.065 \\
\hline $36-47$ & $6.98(2.79-17.47)$ & $3.99(1.57-10.13)$ & $0.004^{*}$ \\
\hline $48-59$ & 16.97 (6.89-41.77) & $9.32(3.73-23.28)$ & $<0.001^{*}$ \\
\hline \multicolumn{4}{|l|}{ Family income } \\
\hline (Brazilian minimum wage) & & & $<0.001^{*}$ \\
\hline 1 & $3.04(2.03-4.56)$ & $2.97(1.93-4.59)$ & $<0.001^{*}$ \\
\hline 2 & $1.97(1.19-3.26)$ & $1.96(1.15-3.32)$ & $0.013^{*}$ \\
\hline 3 & $2.07(1.15-3.73)$ & $2.01(1.08-3.73)$ & $0.027^{\star}$ \\
\hline$\geq 4$ & 1.00 & 1.00 & \\
\hline Assessment of oral health & & & $<0.001^{\star}$ \\
\hline \multicolumn{4}{|l|}{ status by parent/guardian } \\
\hline Excellent & 1.00 & 1.00 & \\
\hline Good & $1.41(0.83-2.39)$ & $1.29(0.75-024)$ & 0.356 \\
\hline Fair & $3.90(2.29-6.65)$ & $3.27(1.87-5.73)$ & $<0.001^{*}$ \\
\hline Bad & $11.02(5.81-20.88)$ & $8.06(3.99-16.23)$ & $<0.001^{*}$ \\
\hline Terrible & $21.08(8.59-51.74)$ & $20.25(3.66-28.78)$ & $<0.001^{*}$ \\
\hline \multicolumn{4}{|l|}{ Visit to the dentist } \\
\hline Yes & $2.62(2.00-3.43)$ & $2.54(1.87-3.44)$ & $<0.001^{*}$ \\
\hline No & 1.00 & 1.00 & \\
\hline
\end{tabular}

* Significant at $5.0 \%$

Table 6

Distribution of children according to the association between dental anxiety and dental pain.

\begin{tabular}{|c|c|c|c|c|c|c|c|c|c|c|c|}
\hline \multirow[t]{3}{*}{ Variable } & \multicolumn{6}{|c|}{ Dental anxiety } & & & \multicolumn{2}{|c|}{ Total } & \multirow[t]{3}{*}{ p-value } \\
\hline & \multicolumn{2}{|c|}{ No } & \multicolumn{2}{|c|}{ A little } & \multicolumn{2}{|c|}{ Yes, quite } & \multicolumn{2}{|c|}{ Yes, very } & \multirow[b]{2}{*}{$n$} & \multirow[b]{2}{*}{$\%$} & \\
\hline & $\mathrm{n}$ & $\%$ & $\mathrm{n}$ & $\%$ & $\mathrm{n}$ & $\%$ & $\mathbf{n}$ & $\%$ & & & \\
\hline Yes & 127 & 54.7 & 32 & 13.8 & 28 & 12.1 & 45 & 19.4 & 232 & 100.0 & $<0,0001 *$, \\
\hline No & 1,503 & 66.3 & 282 & 12.4 & 287 & 12.7 & 195 & 8.6 & 2,267 & 100.0 & \\
\hline Total & 1,630 & 65.2 & 314 & 12.6 & 315 & 12.6 & 240 & 9.6 & $2,499 * \star \star$ & 100.0 & \\
\hline
\end{tabular}

* Pearson chi-square test;

** Chi-square test;

$\star \star \star$ This information was not available for 236 children. 
As with dental anxiety, dental pain was found to be associated with age and family income. In addition, there was a strong association between dental pain and the assessment of oral health status by the parent or guardian. The poorest rating of the child's oral health status by the parent or guardian, as well as the lowest family income, was correlated with the highest percentages of a history of dental pain. The older the child, the greater the dental pain experience, which could be related to an increased caries experience in this age group.

The association of dental anxiety with a history of dental pain may be explained by the notion that dental fear is closely related to invasive procedures 2. Other authors have related dental anxiety or fear to previous painful dental experience or previous negative experience of dental treatment 3,4 .

In agreement with Baier et al. ${ }^{3}$, the etiology of dental anxiety in children is multifactorial, being associated with age, socioeconomic status, oral health status and dental pain experience.

Dental anxiety was related to a history of dental pain in children under five, which suggests that the fear of pain is a factor to be considered, investigated and controlled in dental practice, particularly in pediatric dentistry, since it constitutes the first experience of oral health care.

\section{Resumo}

Este estudo teve como objetivo avaliar a ansiedade e a dor relacionadas ao tratamento odontológico em crianças menores de 5 anos de idade. Este estudo transversal foi realizado com uma amostra de 2.735 crianças, de ambos os sexos. Por meio da aplicação de um questionário em forma de entrevista com os pais ou responsáveis foram obtidas as seguintes informações: dados sócio-econômicos, ansiedade relacionada ao tratamento odontológico e a experiência de dor de dente, assim como a avaliação dos pais em relação à saúde bucal das crianças. A prevalência de ansiedade odontológica foi de 34,7\% e o histórico de dor de dente foi 9,1\%. Verificou-se associação entre essas duas variáveis $(p<0,0001)$. Observou-se também associação entre dor de dente, idade, renda familiar e a avaliação dos pais em relação à saúde bucal das crianças. Saúde bucal comprometida, assim como baixa renda familiar, foram correlacionadas com alta prevalência de histórico de dor de dente. A ansiedade odontológica estava associada ao histórico de dor de dente em crianças menores de 5 anos de idade.

Ansiedade ao Tratamento Odontológico; Pré-Escolar; Odontalgia; Saúde Bucal

\section{Contributors}

M. M. T. Oliveira participated in the data collection and analysis and drafting of the article. V. Colares contributed to the data analysis, to the drafting and revision of the final text. 


\section{References}

1. Nomura LH, Bastos JLD, Peres MA. Dental pain prevalence and association with dental caries and socioeconomic status in school-children, Southern Brazil, 2002. Braz Oral Res 2004; 18:134-40.

2. Majstorovic M, Veerkamp JS. Relationship between needle phobia and dental anxiety. J Dent Child (Chic) 2004; 3:201-5.

3. Baier K, Milgrom P, Russell S, Mancl L, Yoshida T. Children's fear and behavior in private pediatric dentistry practices. Pediatr Dent 2004; 4:316-21.

4. Klingberg G, Berggren U, Carlsson SG, Norén JG Child dental fear: cause-related factors and clinical effects. Eur J Oral Sci 1995; 1:405-12.

5. Caraciolo G, Colares V. Prevalência de medo e/ ou ansiedade relacionados à visita ao dentista em crianças com 5 anos de idade na cidade do Recife. Rev Odonto Ciênc 2004; 46:348-53.

6. Rossato LM, Magaldi FM. Multidimensional tools: application of pain quality cards in children. Rev Latinoam Enferm 2006; 14:702-7.
7. Wijk AJ, Hoogstraten J. Experience with dental pain and fear of dental pain. J Dent Res 2005; 84:947-50.

8. Neverlien PO. Assessment of a single-item dental anxiety question. Acta Odontol Scand 1990; 48:365-9.

9. Armifield JM, Spencer AJ, Stewart JF. Dental fear in Australia: Who's afraid of the dentist? Aust Dent J 2006; 1:78-85.

10. Slade GD, Spencer AJ, Davies MJ, Burrow D. Intraoral distribution and impact of caries experience among South Australian school children. Aust Dent J 1996; 5:343-50.

11. Feitosa S, Colares V, Pinkham J. The psychosocial effects of severe caries in 4-year-old children in Recife, Pernambuco, Brazil. Cad Saúde Pública 2005; 21:1550-6.

Submitted on 10/Mar/2008

Final version resubmitted on 18/Jun/2008

Approved on 25/Jun/2008 